\title{
Intentional poisonings in urban and rural children - a 6-year retrospective single centre study
}

\author{
Agnieszka Mroczkowska-Juchkiewicz', Paulina Krawiec'1, Agnieszka Pawłowska-Kamieniak', \\ Dorota Gołyska', Katarzyna Kominek', Elżbieta Pac-Kożuchowska' \\ ${ }^{1}$ Medical University of Lublin, Poland
}

Mroczkowska-Juchkiewicz A, Krawiec P, Pawłowska-Kamieniak A, Gołyska D, Kominek K, Pac-Kożuchowska E. Intentional poisonings in urban and rural children - a 6-year retrospective single centre study. Ann Agric Environ Med. 2016; 23(3): 482-486. doi: 10.5604/12321966.1219192

\begin{abstract}
Introduction. Intentional poisonings among children and adolescents are a problem not only for paediatricians, but also constitute a big issue for public health. In many countries worldwide, including Poland, an increase has been observed in suicidal behaviours at developmental age.

Objective. The aim of the study was a retrospective evaluation of patients hospitalized due to intentional poisoning in the Department of Paediatrics, Children's University Hospital in Lublin, Poland, in 2007-2012.

Materials and methods. In the study period, 149 patients were hospitalized in the Paediatric Department of the Children's University Hospital in Lublin, due to intentional poisoning with medicines or other chemical substances. The study group comprised 135 girls and 14 boys; The majority of patients $(n=105)$ were urban inhabitants, and only 44 lived in the rural areas. Medical records were analyzed, with consideration of medical, psychological and psychiatric examinations.

Results. Girls constituted as much as $90.6 \%$ of the study group. The majority of patients lived in urban areas $-70.46 \%$. A total of $16.77 \%$ of patients came from incomplete families. Alcohol problem occurred in 19 families. The most frequent cause of a suicide attempt was conflict in the family, followed by school problems. During the 6-year-study period, an upward tendency in the incidence of intentional poisoning was observed, particularly in the first 4 years.

Discussion and conclusion. Suicide attempts in adolescents were mostly undertaken by girls from the urban environment. The majority of those attempts were caused by family problems, including alcoholism.
\end{abstract}

\section{Key words}

suicide attempts, intentional poisonings, children

\section{INTRODUCTION}

Suicides in children constitute one of the most important public health issues. Several phenomena comprise the term 'suicide', including suicidal ideation, suicide attempt, and eventually the act of taking one's own life, i.e. completed suicide. The term suicidal behaviour is usually defined as the presence of suicidal ideation and/or suicide attempt. Recently, numerous studies have focused on problems associated with suicide attempts $[1,2]$. Sociological, psychological and clinical studies indicate that in many countries an increase in incidence of attempted and completed suicides have been observed, and suicidal tendencies have become an important health care problem. [3] According to the American Centers for Disease Control and Prevention, suicides are the third cause of mortality in children aged 15-19 years $[4,5]$. According to the Statistical Yearbook of the Republic of Poland 2010, a total number of 4,480 attempted and completed suicides registered by the police included 227 individuals aged under 19 years [6]. In 2011, these numbers were 5,124 and 326 , respectively [7]. The incidence of suicide attempts varies in different countries. Every year, nearly 900,000 suicide attempts are undertaken worldwide, including approximately 200,000 by children and adolescents.

Address for correspondence: Agnieszka Mroczkowska-Juchkiewicz, Medical University of Lublin, Chodźki 2, 20-093 Lublin, Poland

E-mail: aga_juchkiewicz@poczta.onet.pl

Received: 16 October 2013; accepted: 11 February 2014
Poland is among the countries with mediocre suicide rates (10.1-18.6). Suicide attempts undertaken by children show an increasing tendency, and in numerous countries have become a leading cause of mortality in this age group. The ratio between attempted and completed suicides in children is difficult to determine. According to different researchers it is 8:1, 20:1, 50:1. Precise data are impossible to establish. There is a possibility that suicide attempts in children may be concealed or even diminished. It was proved that adolescent girls attempted suicide more frequently than adolescent boys. However, suicidal attempts undertaken by boys more often led to death. In order to commit suicide, boys prefer more effective and irreversible methods, i.e. hanging or jumping from height $[8,9]$. The relationship between suicidal behaviour and several risk factors, including difficult family situation, social isolation, stressful events, somatic diseases, and adversities of life, is observed. Social risk factors of suicide behaviours include low socio-economic status, low education level, and poverty. The most important familyrelated risk factors are parental separation or divorce, parental mental illness and their possible suicidal behaviours, family conflicts, poor inter-family communication, excessively high or low expectations of parents, and excessive parental control. Moreover, problems with adaptation to new difficult conditions may also result in an increase in the suicidal behaviour rate in childhood. Low self-esteem, introvertism, neuroticism, impulsiveness, passiveness, anxiety, and social maladjustment constitute personality traits related with suicidal behaviours. 
Numerous reports confirm a strong link between suicidal behaviours in adolescents and mental disorders $[2,10]$. Developmental psychologists emphasize that adolescence is a very turbulent period of life. Young people become overly sensitive about their physical appearance, sexuality and emotions. This is commonly known period of rebellion, conflicts and negation of norms and standards. It constitutes a susceptible background for development of distorted selfimage, and auto-destructive disorders, including suicide [1].

\section{OBJECTIVE}

The purpose of the study was a retrospective evaluation of patients hospitalized due to intentional poisoning in the Department of Pediatrics, Children's University Hospital in Lublin

\section{MATERIALS AND METHOD}

The study comprised 149 patients (14 boys and 135 girls) admitted to the Department of Pediatrics at the Children's University Hospital in Lublin, Poland, due to the suicidal ingestion of medications or other substances in the period between 2007-2012. Patients who had taken drugs for psycho-stimulating purposes were excluded from the study group. The youngest patient was 11 years and 6 months, whereas the oldest - 17 years and 8 months; the mean age was 15 years. The majority of children (105) lived in urban areas, whereas only 44 in rural areas. Patients characteristics and medical history were obtained from medical records retrospectively (Tab. 1).

Table 1. Number, gender, place of residence and age of patients hospitalized due to intentional poisoning, in the Department of Paediatrics, Children's University Hospital in Lublin during 2007-2012

\begin{tabular}{|c|c|c|c|c|c|c|c|c|}
\hline Feature & Year & 2007 & 2008 & 2009 & 2010 & 2011 & 2012 & Total \\
\hline $\begin{array}{l}\text { Intentional poisonings } \\
\text { (n) }\end{array}$ & & 11 & 17 & 24 & 37 & 36 & 24 & $\begin{array}{c}149 \\
(100.0 \%)\end{array}$ \\
\hline \multirow{2}{*}{$\begin{array}{l}\text { Gender } \\
\text { (n) }\end{array}$} & Boys & 2 & 2 & 2 & 4 & 2 & 2 & $\begin{array}{c}14 \\
(9.39 \%)\end{array}$ \\
\hline & Girls & 9 & 15 & 22 & 33 & 34 & 22 & $\begin{array}{c}135 \\
(90.60 \%)\end{array}$ \\
\hline \multirow{2}{*}{$\begin{array}{l}\text { Place of residence } \\
\text { (n) }\end{array}$} & Urban & 9 & 12 & 20 & 26 & 25 & 13 & $\begin{array}{c}105 \\
(70.46 \%)\end{array}$ \\
\hline & Rural & 2 & 5 & 4 & 11 & 11 & 11 & $\begin{array}{c}44 \\
(29.53 \%)\end{array}$ \\
\hline Age range (yrs) & & $\begin{array}{c}12- \\
16\end{array}$ & $\begin{array}{c}12- \\
18\end{array}$ & $\begin{array}{c}12- \\
16\end{array}$ & $\begin{array}{c}13- \\
17\end{array}$ & $\begin{array}{c}12- \\
18\end{array}$ & $\begin{array}{c}11- \\
17\end{array}$ & $12-18$ \\
\hline Mean age (yrs) & & 15.0 & 15.3 & 14.5 & 15.0 & 15.3 & 15.0 & 15.1 \\
\hline
\end{tabular}

\section{RESULTS}

Of the 149 patients who attempted suicide, 14 were brought up in an incomplete family, 3 in a foster family, and 8 came from an orphanage or welfare centre. Alcohol abuse was present in 19 families, including 11 living in rural areas (57.8\%). The majority of children (145) undertook a suicide attempt by taking medications, whereas only 4 patients by ingestion of household detergent (floor washing liquid, bubble bath). All 4 children came from a welfare centre. In 19 patients, after psychological consultation, a psychiatric consultation was provided. These children, primarily because of the high risk of repeating the suicide attempt, were referred for further treatment to the children's psychiatric ward. In 9 of them, depression was diagnosed. In 66 patients, the direct cause of the suicide attempt was family conflicts, excluding alcohol abuse and domestic violence. School conflicts were confirmed in 35 patients. In one patient, there was a suspicion that the direct cause of the suicide attempt was sexual assault by a stranger. In 2 patients, the lack of self-acceptance resulting from a chronic disease (severe atopic dermatitis) and developmental defect (lack of one extremity) was observed. In 22 patients, suicidal attempts were a form of manipulation of the environment, especially their parents. This was an attempt to enforce the purchase of a new item, decrease in school requirements, or even excused from household chores. One patient was admitted due to marijuana use. In 23 female patients, physical examination revealed evidence of deliberate self-mutilation. Five patients were placed under the supervision of a probation officer.

In 22 patients, psychological evaluation was not performed. Two of these children left hospital wilfully and 20 did not consent for psychological examination. In 4 patients, this

Table 2. Characteristics of the study group with consideration of family situation, causes of suicide attempts, and possibly further psychiatric treatment

Year $2007200820092010 \quad 2011 \quad 2012 \quad$ Total

Feature

\begin{tabular}{|c|c|c|c|c|c|c|c|}
\hline Incomplete family (n) & 0 & 2 & 3 & 3 & 4 & 2 & $\begin{array}{c}14 \\
(9.39 \%) \\
\end{array}$ \\
\hline $\begin{array}{l}\text { Children from orphanage or } \\
\text { welfare centre }(n)\end{array}$ & 0 & 1 & 2 & 0 & 4 & 1 & $\begin{array}{c}8 \\
(5.36 \%) \\
\end{array}$ \\
\hline Foster family (n) & 0 & 0 & 0 & 0 & 2 & 1 & $\begin{array}{c}3 \\
(2.01 \%) \\
\end{array}$ \\
\hline Alcoholism in family (n) & 3 & 1 & 6 & 3 & 4 & 2 & $\begin{array}{c}19 \\
(12.75 \%) \\
\end{array}$ \\
\hline School problems (n) & 3 & 6 & 3 & 9 & 4 & 10 & $\begin{array}{c}35 \\
(23.48 \%) \\
\end{array}$ \\
\hline Family conflict (n) & 5 & 8 & 8 & 11 & 14 & 20 & $\begin{array}{c}66 \\
(44.29 \%) \\
\end{array}$ \\
\hline Physical violence in family (n) & 2 & 3 & 6 & 4 & 3 & 5 & $\begin{array}{c}23 \\
(15.43 \%) \\
\end{array}$ \\
\hline Sexual molestation $(n)$ & 0 & 0 & 0 & 0 & 1 & 0 & $\begin{array}{c}1 \\
(0.67 \%) \\
\end{array}$ \\
\hline $\begin{array}{l}\text { Lack of acceptance of body } \\
\text { image (n) }\end{array}$ & 1 & 1 & 0 & 0 & 0 & 0 & $\begin{array}{c}2 \\
(1.34 \%) \\
\end{array}$ \\
\hline Manipulation attempt (n) & 1 & 2 & 1 & 8 & 5 & 5 & $\begin{array}{c}22 \\
(14.76 \%)\end{array}$ \\
\hline Self-harm (n) & 0 & 3 & 4 & 2 & 6 & 8 & $\begin{array}{c}23 \\
(15 \%)\end{array}$ \\
\hline $\begin{array}{l}\text { Supervision of probation } \\
\text { officer }(n)\end{array}$ & 0 & 0 & 0 & 0 & 0 & 5 & $\begin{array}{c}5 \\
(3.35 \%) \\
\end{array}$ \\
\hline Depressive disorders (n) & 0 & 0 & 5 & 2 & 0 & 2 & $\begin{array}{c}9 \\
(6.04 \%) \\
\end{array}$ \\
\hline $\begin{array}{l}\text { Further psychiatric treatment } \\
\text { (n) }\end{array}$ & 2 & 2 & 3 & 7 & 3 & 2 & $\begin{array}{c}22 \\
(14.76 \%) \\
\end{array}$ \\
\hline $\begin{array}{l}\text { Lack of psychological } \\
\text { consultation (n) }\end{array}$ & 2 & 2 & 4 & 3 & 9 & 2 & $\begin{array}{c}22 \\
(14.76 \%) \\
\end{array}$ \\
\hline Repeated suicide attempt (n) & 1 & 0 & 0 & 0 & 0 & 3 & $\begin{array}{c}4 \\
(2.68 \%)\end{array}$ \\
\hline
\end{tabular}

$\mathrm{n}$ - number of patients 
was the subsequent (second) suicide attempt (Tab. 2). These patients were not particularly burdened with family conflicts, neither with behaviour nor depressive disorders.

More than one drug was ingested by 45 . The most commonly used medicines were drugs affecting the nervous system (sedatives, antidepressants, hypnotic and antiepileptic and antipsychotic medications), followed by non-steroid anti-inflammatory drugs (Tab. 3).

Table 3. Medications and chemical substances used for intentional poisonings in the study group

Year $2007 \quad 2008 \quad 20092010 \quad 20112012$

Type of drug

\begin{tabular}{lcccccc}
\hline The mixture of various drugs $(\mathrm{n})$ & 2 & 7 & 8 & 6 & 14 & 9 \\
\hline Drugs affecting nervous system $(\mathrm{n})$ & 7 & 7 & 10 & 10 & 8 & 10 \\
\hline Acetaminophen $(\mathrm{n})$ & 0 & 2 & 2 & 4 & 5 & 4 \\
\hline NSAIDs $(\mathrm{n})$ & 1 & 1 & 3 & 10 & 4 & 1 \\
\hline Detergents $(\mathrm{n})$ & 0 & 0 & 0 & 0 & 4 & 0 \\
\hline Drugs affecting cardiovascular system $(\mathrm{n})$ & 1 & 0 & 0 & 2 & 0 & 0 \\
\hline Antibiotics and chemotherapeutics $(\mathrm{n})$ & 1 & 0 & 0 & 3 & 0 & 0 \\
\hline Vitamins $(\mathrm{n})$ & 0 & 0 & 1 & 0 & 0 & 0 \\
\hline Laxatives $(\mathrm{n})$ & 0 & 0 & 0 & 1 & 1 & 0 \\
\hline Drugs affecting respiratory system $(\mathrm{n})$ & 0 & 0 & 0 & 1 & 0 & 0 \\
\hline Total number of poisonings & 11 & 17 & 24 & 37 & 36 & 24
\end{tabular}

NSAIDs - Non-steroid anti-inflammatory drugs; $\mathrm{n}$ - number of poisonings

The majority of patients were admitted in a good or relatively good condition and required only symptomatic treatment. No cases of death due to poisoning were observed. In a few patients who ingested a high dose of acetaminophen (over $100 \mathrm{mg} / \mathrm{kg}$ ), a high plasma acetaminophen level and/or abnormal liver biochemical test results were observed. These patients required acetylcysteine administration. Two patients with acute hepatic failure were referred to the Department of Paediatric Gastroenterology, Hepatology and Nutrition at the Children's Memorial Health Institute in Warsaw. None of these patients required liver transplantation.

\section{DISCUSSION}

The problem of suicides may concern all age groups and both genders, and because of that fact it is a considerable public health problem. Developmental factors modify the clinical features of suicidal behaviours in children and adolescents. The comparative data on acute poisonings in the Lublin Macroregion during 1982-1989 and 1990-1994 showed an almost constant poisoning index during the study period. However, in that study, poisonings were not classify into intentional or accidental [11]. During the period of 30 years until 1990, in many countries worldwide, there was noted a nearly three-fold increase in the number of suicides among the population aged 15-24. At that time, in the West European countries there were implemented national programmes to prevent suicides. In Poland, there are two inconsistent statistical registers of suicides. One has been developed based on the Death Certificate, and the other - based on the reports by the Police Headquarters [12]. Their interpretation is limited due to several profound differences between these data.
The risk factors for suicidal behaviours include age, gender, dysfunctional family, residence, mental disorders, school problems, low self-esteem, and previous suicide attempts. $[4,13]$.

Suicide attempts are usually undertaken during puberty. This is the period_of biological and emotional instability $[5,12]$.

A considerable body of evidence indicate female gender as a risk factor for suicide behaviours [4, 14-18]. The presented study confirmed this observation: girls constituted $90.6 \%$ of the patients analyzed.

It is well established that children who undertake suicide attempts come from dysfunctional families more frequently, compared to those from the control group $[4,19]$. The current study also confirmed a relationship between a widely understood family pathology and an increased risk of suicide attempts. Alcoholism in a family promotes suicide attempts particularly during puberty $[4,19]$. In this study, this problem concerned $12.75 \%$ of patients.

Urban inhabitants constitute the majority of patients who undertake suicide attempts $[13,20]$. In the study by Lifshitz M. and Gavrilova V., who evaluated a group of 4,008 patients with self-poisonings, $72 \%$ lived in urban areas [4]. In the current study, this percentage was similar $-70.46 \%$. In the study by Jarosz M., concerning the sociological analysis of suicides in Poland from the international perspective within the last 50 years, several tendencies were observed, including: a more rapid increase in the number of suicides among the rural population and adolescents, a quantitative increase in this phenomenon in the general population, and significant changes in the occupational structure [9].

In $49-64 \%$ of underage victims of suicides, depressive disorders were the most conducive for committing this act. It is considered that $2.5 \%$ of children and $8.3 \%$ of adolescents suffer from depression and it occurs equally in both genders $[5,12]$. Due to its prevalence, depression is currently thought to be a civilisation disease. Studies of psychopathological conditioning of suicides indicated that $25 \%-50 \%$ of people who committed suicide suffered from severe mental disorders. It is estimated that $15 \%-25 \%$ of patients with depression, in the course of rapid cycling bipolar disorder, commit suicide [8]. In the presented study, depressive disorders were diagnosed in $6.04 \%$ patients, and all of them were referred for further psychiatric treatment.

A large group of patients at an increased risk of a suicide attempt are children with school problems. Conflicts in the peer group, lack of acceptance, also of oneself body-image, overloading with education, and lack of possibility to meet expectations, are important selected risk factors for suicide attempts [21-23]. In this study, school problems were the second cause, following family conflicts, for undertaking a suicide attempt.

Lack of acceptance of oneself body-image was observed in 2 patients: one patient suffered from a congenital lack of one extremity, and another from severe dermal changes in the course of atopic dermatitis.

Children who undertook a subsequent suicide attempt constitute a special group. In this study, there were 4 such patients $(2.68 \%)$, whereas in the study by MordasewiczGoliszewska, $17 \%$ of the children repeated a suicide attempt. These patients were diagnosed as having behavioural, personality and emotional disorders, while in their families: depression in the mothers, alcoholism, and suicide attempts 
were noted [5]. It should be highlighted that in adolescents, repeated suicide attempts are more frequent and less distant in time than in adults [24].

Drugs are the most common cause of suicide attempts, including widely available over-the-counter medicines (OTC). According to various researchers, among OTC medicines the most frequently used are non-steroid antiinflammatory drugs, particularly acetaminophen $[4,13]$. In patients aged 9-15 hospitalized due to a suicide attempt during 1991-1995 in Łodź, Poland, hypnotic and psychotropic drugs were the most commonly used. This phenomenon was explained by the widespread use of drugs among these groups by adults, and consequently, their easy availability for children [25]. Mordasewicz-Goliszewska et. al. found that medicines affecting the central nervous system were the most common agents used for suicide attempt [5]. In the presented study, most of the children used a single drug, including drugs affecting the central nervous system (sedatives, antidepressants, hypnotic and antiepileptic drugs), followed by non-steroid anti-inflammatory drugs. For self-poisoning, detergents were used in 4 cases.

Deliberate self-mutilations, presented predominantly in girls as cuts on forearms, are one of the most frequent alarming signs of increased risk of suicide attempt [26-28]. In children hospitalized in the Paediatric University Hospital in Białystok, Poland, due to suicide attempt, deliberate selfmutilations was primarily observed among 13-15-year-old girls [20]. In the presented study, deliberate self-mutilations were observed in $15 \%$ of patients in the form of cuts on the skin of the forearm.

Numerous epidemiological studies revealed risk factors for suicide attempts. Based on that knowledge, effective interdisciplinary methods of suicide prevention in children should be created.

The WHO's worldwide Suicide Prevention Programme (SUPRE) developed guidebooks concerning suicide preventive methods. The implementation of the National Programmes for Suicides Prevention in various countries evokes hopes for effective interventions [12]. According to the Appeal for Suicides Prevention among Adolescents, extremely important in suicide management are reliable scales of suicidal behaviours among adolescents and creation of effective preventive actions [29].

\section{CONCLUSIONS}

1. The results of this study do not enable the formulation of any general epidemiological conclusions. Further studies are therefore required to estimate a reliable incidence of suicide behaviours in children, and to create proper preventive interventions.

2. The results obtained are in agreement with the hypothesis that suicide attempts are primarily undertaken by girls and urban inhabitants.

3. The most common causes of suicide attempts in childhood are family conflicts, including alcohol abuse.

\section{REFERENCES}

1. Napieralska E, Kułaga Z, Gurzkowska B, Grajda A. Epidemiologia zgonów dzieci i młodzieży z powodu samobójstw w Polsce w latach 1999-2006. (Epidemiology of deaths due to suicides among children and adolescents in Poland during 1999-2006)Probl Hig Epidemiol. 2010; 91(1): 2-98 (in Polish).

2. Gmitrowicz A. Uwarunkowania zachowań samobójczych młodzieży. (Conditioning of suicidal behaviours of adolescents.) Suicydologia. 2005; 1(1): 71-76 (in Polish).

3. Cekiera CM. Psychologiczne i aksjologiczne aspekty samobójstw. (Psychological and axiological aspects of suicides). Suicydologia. 2005; 1(1): 21: 32 (in Polish).

4. Lifshitz M, Gavrilov V. Deliberate self-poisoning in adolescents. IMAJ. 2002; 4: 252-254.

5. Mordasewicz-Goliszewska M, Albrant-Kuzia G, Słowikowska R, Pasko J, Stąpel P, Grygalewicz J. Celowe zatrucia u dzieci i młodzieży w materiale kliniki ogólnopediatrycznej. (Intentional poisonings among children and adolescents in the material of the General Paediatric Clinic). Pol Merk Lek. 2006; XXI(121): 24-28 (in Polish).

6. Rocznik Statystyczny Rzeczpospolitej Polskiej 2011. (Statistical Yearbook of the Republic of Poland 2011) www.stat.gov.pl/cps/rde/ xbcr/gus/rs_rocznik_statystyczny_rp_2011.pdf

7. Rocznik Statystyczny Rzeczpospolitej Polskiej 2012. www.stat.gov.pl/ cps/rde/xbcr/gus/RS_rocznik_statystyczny_rp_2012.pdf

8. Woźniak E, Talarowska M, Orzechowska A, Florkowski A, Gałęcki P. Rozpowszechnienie prób samobójczych wśród dzieci i młodzieży. Prevalence of suicide attempts among children and adolescents). Pol Merk Lek. 2013; XXXIV(201): 154-157 (in Polish).

9. Jarosz M. Samobójstwa w III Rzeczypospolitej w perspektywie światowej. Analiza socjologiczna. (Suicides in the Third Republic of Poland from the international perspective). Suicydologia. 2005; 1(1): 13 (in Polish).

10. Sumiła A, Sulska E. Zachowania samobójcze u pacjentów hospitalizowanych psychiatrycznie na oddziale młodzieżowym. (Suicidal behaviours among patients hospitalized in psychiatric juvenile ward). Psychiatria. 2006; 3(3): 128-132 (in Polish).

11. Szajner-Milart I, Wójcik-Skierucha E, Zinkiewicz Z. Porównawcze badania epidemiologiczne ostrych zatruć u dzieci na terenie Makroregionu Lubelskiego w latach 1982-1989 i 1990-1994. (The comparative epidemiological study of acute poisoning in children in Lublin Macroregion during the periods 1982-1989 and 1990-1944). Przegl Pediatr. 1998; 28(4): 287-290 (in Polish).

12. Steele M, Doey T. Zachowania samobójcze u dzieci i młodzieży. Część I: Etiologia i czynniki ryzyka. (Suicidal behaviours in children and adolescents. Part I. Etiology and risk factors). Med. Prakt Psych. 2008/03: 76-93 (in Polish).

13. Zielińska-Duda H, Koszczyńska J, Czerwionka-Szaflarska. Analiza zatruć chemicznych u dzieci i młodzieży. (Analysis of chemical poisonings among children and adolesdcents). Med. Ped Współ Gastroenterol Hepatol Żyw Dziecka. 2011; 13(4): 218-223 (in Polish).

14. Bentur Y, Obchinikov N.D, Cahana A, Kovler N, Bloom-Krasik A, Lavon O, Gurevych B, Lurie Y. Pediatric Poisonings in Israel:National Poison Center Data. IMAJ. 2010; 12: 554-559.

15. Sahin S, Carman KB, Dinleyici EC. Acute poisoning in children; Data of Pediatric Emergency Unit. Iran J Pediatr. 2011; 21(4): 479-484.

16. Andiran N, Sarikayalar F. Pattern of acute poisonings in childhood in Ankara: what has changed in twenty years? Turk J Pediatr. 2004; 46(2): 147-152.

17. Sinno D, Majdalani M, Chatila R, Musharrafieh U, Al-Tannir M. The pattern of self-poisoning among Lebanese children and adolescents in two tertiary care centres in Lebanon. Acta Paediatr. 2009; 98(6): 1044-1048.

18. Marbella AM, Yang H, Guse CE, Meurer JR, Layde PM. Adolescent hospital discharges associated with self-poisonings in Wisconsin, 2000-20012. WMJ. 2005; 104(7): 59-64.

19. Kerfoot M, Dyer E, Harrington V, Woodham A, Harrington R. Correlates and short-term course of self-poisoning in adolescents. $\mathrm{Br}$ J Psychiatry. 1996; 168(1): 38-42.

20. Pawłowicz U, Wasilewska A, Olański W, Stefanowicz M. Epidemiological study of acute poisoning in children: a 5-year retrospective study in the Paediatric University Hospital in Białystok, Poland. Emerg Med J. 2012; August 31, doi:10.1136/emermed-2012-201376.

21. American Academy of Child and Adolescent Psychiatry. Practice parameter for the assessment and treatment of children and adolescents with suicidal behavior. J Am Acad Child Adolesc Psychiatry. 2001; 40(7 suppl.): 24S-51S.

22. Hurry J. Deliberate self-harm in children and adolescents. Int Rev Psychiatry. 2000; 12: 31-36.

23. Hawton K, Hall S, Simkin S, Bale L, Bond A, Codd S, Stewart A. Deliberate self-harm in adolescents: a study of characteristics and trends in Oxford, 1990-2000. J Child Psychol. 2003; 44: 1191-1198. 
24. Jeanneret O. A tentative epidemiologic approach to suicide prevention in adolescence. J Adolesc Health. 1992; 13: 409-414.

25. Kotwica M, Czerczak S. Intentional poisonings in children below 15 years of age in the city of Lodz. Vet Hum Toxicol. 2002; 44(4): 248-250.

26. Shek DT, Yu L. Self-harm and suicidal behaviors in Hong Kong adolescents: prevalence and psychosocial correlates. Scientific World J. 2012; 2012: 932540. doi: 10.1100/2012/932540.

27. Swahn MH, Ali B, Bossarte RM, Van Dulmen M, Crosby A, Jones AC, Schinka KC. Self-harm and suicide attempts among high-risk, urban youth in the U.S.: shared and unique risk and protective factors. Int J Environ Res Public Health. 2012; 9(1): 178-191.

28. Kidger J, Heron J, Lewis G, Evans J, Gunnell D. Adolescent self-harm and suicidal thoughts in the ALSPAC cohort: a self-report survey in England. BMC Psychiatry. 2012; 2: 69-81.

29. Gmitrowicz A. Apel dotyczący prewencji samobójstw młodzieży. (Appeal concerning prevention of suicides among adolescents) www. krc.pan.pl/index.php?option=com_content\&view=article\&id=83:apeldotyczcy-prewencji-samobojstw-modziey\&catid=32:aktualnoci-iwydarzenia\&Itemid $=46$ 